\title{
GLOBALIZATION AND THE CRISIS IN LAW: RETHINKING ETHICS AND MORALS IN THE POSTMODERN STATE
}

DENDASCK, Carla ${ }^{1}$

SILVA, Adonias Osias²

DENDASCK, Carla; SILVA, Adonias Osias - Globalization and the crisis in law: Rethinking ethics and morals in the postmodern State - Magazine Multidisciplinary Scientific Knowledge Center - Vol. 1. Year. 1. March. 2016, pp: 98-119 - ISSN:09592448

\section{SUMMARY}

This test aims a critical analysis on the technological and economic globalization and its impact on positive law, with its formal face normativista logic the contexts that are increasingly complex and changeable. Starting from this premise, it is intended to assess how the ethics and morals can serve from the North in this paradigm shift that is necessary for an application of the law that best meets the aspirations of the citizen in a society in constant change. The aim is to analyze the role of the right under this new globalization bias and its relevance to the modern man.

Key Words: Ethics. Morale. Globalization. Right

\section{INTRODUCTION}

Is General sabença that the trajectory of the man on the planet, starting in the caves until homo sapiens, when man began to become aware of your intelligence and set up

${ }^{1}$ Doctorate in Psychoanalysis, postdoctoral fellow in Clinical Psychoanalysis, master in Bioethics-Director of the Center for research and advanced studies-email: prof.dra.csd@hotmail.com.

${ }^{2}$ Lawyer, graduate studies in tax law; Master's degree in law at Escola Paulista de Direito; adonias.silva@unifesp.br. 
his freedom to overcome the obstacles that always crossed his path, has always been marked by the participation in the construction of law and justice.

Even in the dawn of civilization, when hadn't an idea of improved law and justice as we have nowadays, man has always fought to be the actor of his own history and within this tune became a political and moral, which acted within his concept of ethics and morality.

In fact, one can distinguish the man from other living beings exactly for his intellectual development, which in turn is directly related to his conduct in society, that is, in its moral procedure is demonstrated through their attitudes on collective coexistence with their peers, which is not happening with the other living beings that Act simply by instinct. That his position among the other self-moving machines of nature is that gives a prominent position as social Dominator (REALE, 1994).

Since the social customs transmitted from father to son the relationships of social groups have evolved from simple paradigms of co-existence until the command structure more solid such as the positivado law, and that as a consequence of the eminently gregarious of the human being from their social coexistence did exsurgir the right, as a social phenomenon of their own culture with its rules and sanctions.

And to ratify this reality there is a Latin principle that says: "ubi societas, ibi ius est" (where there is society, there will be a right). This is the starting point of this test, since the society has evolved, it has become global, and the positive law with its formal regulations, it seems, can no longer meet the aspirations of this modern man that in a globalized world follows in his eternal journey in pursuit of Justice.

Globalization, which came hand in hand with the technological revolution and the economic changes, after won its first phase of installation, which is the integration of world markets, now presents us with a new challenge are the ramifications and impacts on legal institutions. The big challenge is to know which the effectiveness and scope of legal institutions and legal instruments for this new reality of globalised man. 
Beside that, you can't forget the role of ethics and morality to the modern law, foundations for a just society and correct. Such a fact can be seen by the simple fact that, in practice, the practical application of the law is done through distributed justice for a man - the judge - who the legal system lies with the Honourable mister to solve the dispute between the parties in dispute in search of a sentence.

In comparing the procedural process in search of the sentence what you realize is that they are placed in confrontation not only legal, but to all ethical and moral principles that procedural law requires not just the litigants as well as his own judge. The sticking point is how to be ethical in degenerate corruption brought within the globalization and their technological systems, where you can embezzle from a simple choice of liquidator of condo until an election to choose our rulers.

Economic globalization imposes on the duty of man be Rico, to have, to possess at all costs, and technological innovations are the tracks that will lead the locomotive of the dishonesty, under the guise of going that the ends justify the means, farther and humans of ethical and moral values received from cradle. And in this system the nexted "Gerson's law", of ease at any cost, is the law, with all its aspects and determinants.

It's about the crisis in the right to be treat in this text, taking into account aspects of globalization, which has made the world a global village, and took with him the values of ethics and morals transmitted to us by our founding fathers. We live today in increasingly complex contexts and mutable, that clamor for a contextualized law, a law that meets the current needs of man, which are no longer the same man inserted in the context of the last century.

What can be said of concrete is that the State and the law, modeled on traditional we are deployed in society today, not suited to social developments experienced by humans within society. Today, more than ever, the right needs to take other directions if you want to meet the aspirations of this man. The right has to turn to alternative means, that is, the law must be a right of negotiation, of round tables, arbitration and mediation. 
What is certain is that the paths that brought us this far will not be the same that will take us from now on. And on account of this reality is valid to analyse to what extent the right positivado, with a formal logic and inflexible, can meet the satisfaction the aspirations of this globalised man, in particular with regard to the ethical and moral aspect. Is no need to maintain the ethics and morals without losing sight of the law and its correct application to the specific case.

\section{GLOBALIZATION IN THE MODERN STATE}

History has shown that man has always fought for improvements in their living conditions. Human conglomerates already took the form of cities about $3500 \mathrm{BC}$ and its social context emerged the warriors with their primitive weapons were forged for the defence of the social group. From this arose the constructors of its mansard roof, who dominated the use of water, and those, who with his wisdom learned to interpret natural phenomena and became their priests and judges.

From that primary development man and society evolved in several ways and at several stages, that you don't want to here parses them, since this paper does not lend itself to this desideratum. However, it is worth noting here only the abolutismos that marked the early days of the modern State, which brought as a characteristic the monopoly of the use of violence by the despots, that absolute way held the power at all cost, being not only legislators but also judge their own will.

The State, in order to maintain social peace threatened or violated, forbade the autotutela and called for responsibility to resolve disputes. From that moment the State now has the function of applying the law to the specific cases submitted to it and fix the conflict.

As a result the State as holder of the order, law and justice by restricting the field of rulers to the strict limits of the law, giving the judiciary the exclusive competence for judging and settling conflicts, and this makes it through the jurisdiction. The word jurisdiction comes from the composition of two words: the Latin noun jus, juris, meaning 
"right", more the third conjugation of the verb dicere, meaning "say", "say", "express". Thus, jurisdiction is the power that the State has to say the right.

However, the jurisdiction is inert, according the Latin principle: "nemo iudex $t$ and sine; $N E$ procedat iudex $t$ officio (no judge without actor; the judge shall ex officio). Hence the art. 2 of the code of Civil procedure, which thus prolata: "no judge will provide the judicial protection otherwise as part or interested to apply, in the cases and legal ways".

For this reason, so that the State can offer the performance and exercise its role as a mediator of disputes is no need that the holder of the conflicting interests in the legal relationship of law material has initiative and go knocking on doors of the judiciary. By appropriate, is valid to note that although the State does not have the jurisdiction to start, once caused the jurisdictional function of the State, the process will be developed by impulse official until its completion with a sentence that put an end to the deal.

With the population growth and the economic, technological and social growth, the demand of citizens tapping at doors of the judiciary are proportionally larger than the answers given to those seeking an answer to their demands and disputes. And the result of this is that the judiciary, which no longer meets the demands there taken, a judicial activism which does not correspond to the concerns of citizens.

Today, with globalization, the problems faced by the society are completely different from those experienced by a generation ago, and the trend is an increase of these difficulties, and the certainty that we have is that the judiciary is not prepared for the changes that present themselves to the next generation, which we'll discuss in the following lines.

When it comes to what globalization has in mind is a serious analysis of the processes and interrelated and changes that are happening on the world stage, and with it the entire way of thinking, acting and living in society is changing substantially. These changes affect not only the economic and social structures that interfere directly in current legal production and, as a result, in the form of thinking and making the right. 
The first point that you can't fail to mention is the question of the sovereignty of the nation-State in the face of the growth of multinacionalismo and transnationalism. With the rise of multinational corporations and the emergence of supranational and transnational agents rampant brought by globalization, the nation State sees its strength mitigated as regards regulation and structuring of economic regulations, as well as regarding the protection of the individual and of society. What was once exclusive competence of the nation State, from the globalization will be the target and interest of other transnational and multinational institutions.

Multinational companies, with their capacity for expansion, both of production and other operations around the world, in spite of its importance for the social and economic development, impose the right a completely different way of thinking brought molds of the past century and that has been perpetuated in the history. The ease with which these companies have to move their factories from one country to another as well as their potential world trading, requiring the right an overview and more open and less systematic, closed and located as the current.

The relevance of these companies for the global economy leads to a change of focus to social relationships, with all its complexity, require the lawyer not only the national perspective, however, a look ' beyond borders ', i.e. a global look. Even that became common place if you hear that "the world is a global village," meaning that the fences, walls and the boundaries that separated us from our neighbors, now no longer can be glimpsed.

Such reality affects the right to all levels and has its developments in ethical values, moral and good behavior that is required of the citizen entered in this globalized social context. Exposed to all the risks brought about by globalization, this citizen, that a judicial demand response to your demand, you don't find the right more than concepts and established institutes, formally and determined, who can't meet your needs within this global complexity.

For this reason, we can say that globalization points to a change in civil, criminal, administrative, business and, above all, international law, you need to adapt constantly 
to meet new and unusual situations that until some time ago were thought to exist, such as the global trade and financial markets Union that, notwithstanding its flexibility for creating United capital globally and the facilitation of the free flow of investment without borders, a new reality and diffused to the current law.

Another factor that must be thought of in this globalized world is the issue of the growth of regional economic blocs, as it directly affects the modus operandi of the right as is in our society. What is more common today, and that has increased every year, is the exchange between regional trade blocks, namely, the reduction of trade barriers between the Nations. Just remember to acronyms as FTAA, MERCOSUR, UEA, just to name a few of these blocks that join with commercial affinities. What is certain is that today the international trade is a reality and the neoliberal concepts which were more the hegemonic, are opening the doors of many nations formerly closed to dialogue, as is the case in Eastern Europe, the former Soviet Union and, with positive reflections on China.

The international free trade and the emphasis exacerbated that private markets somehow decentralizes and reduces the role of Government, which has always been the regulator of the economy. This change to the free trading of such rides that influenced directly the economic policy of "Uncle Sam", as well as European economic policy in General, leading to the creation of entities such as the IMF, the IBRD (as well as regional banks and the GATT), and spreads its effects around the globalized world.

And if all those changes weren't enough to draw the graph of the current society, you can still talk on the world-wide trend to democratisation, the protection of human rights, taking a much greater interest in the field of law, given the jurisdictional function of the State initially pointed to. Parallel to the glaring manifestations by economic changes, a tremendous effort at the international level, for the creation of liberal policies, which aim to protect the individual's human rights, as well as the control of arbitration and the strengthening of legal institutions which come really judicial request to provide citizens, vis-à-vis its diffuse and collective interests. 
Parallel to all this you'll also find the NGOs that are transnational and supranational actors who appear in this scenario in order to protect human rights, the rights of the underprivileged, the right to a sustainable environment, the rights of indigenous peoples, the rights of ethnic minorities, the question of the affective in society, homo just to name some of them. You can't forget that all these issues are part of everyday life of the citizen and society looks forward to a satisfactory answer and you come to find that modern man who, it seems, was asked to leave the cave, however was not given the means to move on, which is why still engrossed to everything you see around you feeling helpless and unprepared to face this new reality.

To analyze all this global problem is the patent law has been endeavouring to plumbing and driving of the conflicts and clashes have arisen within society, which is why one should speak not only in a radical and urgent, in a total fitness of concepts traditionally used, in such a way that, in the same way as the man came out of the cave the right also do the same way and come to find that modern man in the midst of a chaotic society, a globalized world, and an experience of widespread conflicts at all levels.

\section{POSITIVIST LAW AND FORMAL LOGIC}

It is not possible to speak in positivism in legal field without tow to the figure of Hans Kelsen. In fact, although it is considered the father of positivism is worth highlighting that all ab initio positivist doctrine was being built over the years and had his leading role in the development of law as a science.

For Kelsen, the law should be understood as norma, divorced from any social or evaluative design. Just think of this mode is that the centerpiece of his work, known as pure theory of law, is the release of that legal science to all the content, by the optics of Kelsen, not her own. By proposing that split the German jurist aims to give legal autonomy science of its own, entirely free of elements that do not belong to them.

For Kelsen pure legal science should be unmistakable to psychology, sociology, politics and morals. Although such Sciences relate in some way to the right and cross your way most of the time, yet the legal science cannot be impregnated with such 
concepts outside his area of expertise. Such understanding, although it sounds strange to the ears, has its value when you want to talk about justice, as if using a precise language and rigidly logical, Kelsen abstracted Right concept the idea of Justice.

Justice is always and invariably closely tied with the values (always variables) adopted by the one who invokes (whether by sociological, psychological or moral arguments), not being a concept of law universally valid, due to the inaccuracy and fluidity of meaning, do what is right for a given context or society that wouldn't be fair to another.

In Joram's vision the right is limited to a set of rules represented by the category of requirements "should be", and thereby brings the facts to a legal scale or antijurídico. With that one realizes clearly that Kelsen creates an ethics based on the distinction between be and should be. In other words, Kelsen draws a distinction between how things are and the way things should be, and this relationship between "be" and the "must-be" ends in two distinct aspects, and which are crucial in its design. The first of these aspects relates to the fact that this distinction between being and must-be serves to differentiate between two ways in which one can study law: the first is the vision of law as it is, and the second is the view of the law as it should be. The second aspect that this distinction also serves to make a divisive landmark between the realm of factsrelated to be-and the Kingdom of the standards-should be related. Therefore, the following equation: the failure to comply with the obligation (the absence of fact given), implies sanction (should be). In clearer words: the failure (duty), there should be a penalty (sanction established by the standard).

In this context, Kelsen notes that the standard is a product of the will, drawn up with the purpose to regulate human conduct and that serves as an interpretation. Here it is necessary to highlight that for positivism to standard has no validity for the sense of being fair, but for the simple fact of being connected to other standard considered superior he called fundamental standard. It is from this methodological concept of fundamental standard which the jurist can create a systematization of an entire legal order. 
One of his more far-reaching practical theoretical concepts is the idea of legal system as being a tiered set of structured legal rules in the form of a pyramid abstract, punctuated and dominated by the State Constitution, which makes the other legal rules of lower hierarchy (the various infra-constitutional laws and other normative acts). This theoretical conception is that extracts the concept of constitutional rigidity, which is enable and require a system to protect the integrity of the Constitution. Although there are controversies about the creation of the normative pyramid, for the purpose of this essay is attributed to Kelsen.

Another major contribution of the jurist to the practical world of law was the Constitution of Austria from 1920, drafted under his inspiration. In the shadow of the influence of Kelseniano thought this letter Austrian Policy, marketing to previous innovated positive law the concept of concentrated control of constitutionality of laws and normative acts as judicial function by a Constitutional Court, charged with the exclusive function of the integrity of the Constitution.

From there the constitutional jurisdiction can be split in two parts: the constitutional jurisdiction (concentrated control of constitutionality) and diffuse constitutional jurisdiction (diffuse control of constitutionality). This last mode of guard of the Constitution (diffuse) was already practiced in the United States of America.

In the Brazilian legal system, under the auspices of the Federal Constitution of 1988, the constitutional jurisdiction is practiced both ways: the concentrate, through actions of the competence of the Supreme Court, and the diffuse, executed in the records of any actions (and resources to these inherent) within the jurisdiction of any court, whether judges or courts.

Therefore, when discussing Kelsen we cannot lose sight of the main issue of his thinking which is the validity of the rule of law and their hierarchy, being this one of the most important aspects of his theory.

Before the above one can see that the positivist law is a set of rules governing human conduct and these standards, in turn, when valid and legitimately perceived failure 
acquire power to establish sanctions, because of its structure, is characterized as a coercive order and that only applies if you are umbilically linked to other standard.

The big problem that presents itself in relation to legal positivism is that even though he is a system of rules governing the conduct of man in society, but the inflexibility of the right positivado can not meet the concerns of that same man. This treadmill is worth mentioning criticism made by Dworkin to legal positivism in saying that positivism is so dogmatic that "the law often becomes what the judge says" (DWORKIN, 2003, p. 4). This criticism Ronald Dworkin makes a counterpoint to the positivist law showing a theoretical model that is scoped to give an adequate response to the issue of interpretation, which he calls the integrity of law

Well, this intolerant dogmatism of legal positivism, which ultimately reduce the law the statement of certain judges is that by taking the hope of citizens, relegating the right only to the world of ideas, what should be, and not the real world, what is expected when it entered the judiciary with a demand: the concreteness of the lawsuit. Don't talk about here in justice, because as has been mentioned, the legal positivism doesn't have that claim to justice, but simply aims to provide a universally valid concept of law, apart from other social realities. The point here is that at least the so longed jurisdictional provision take effect in fact and in law and not only theorized in legal provisions, verbalized by toga.

\section{ETHICS AND MORALS IN THE RIGHT}

When it comes to ethics and morals in the right one cannot fail to mention that the conduct of an individual in relation to the other, in every social context in judicial fights, carried out to justice, always has a strong moral slant.

The only difference between the ethical and moral postulates and the right is that the latter has its coercive force governed by the legal system, that all superimposed with its rules and standards defined, which dictates bring with them the penalties liable to whom they submit. 
The positivist jurist Hans Kelsen (2001:36), already mentioned in this text, brings an important contribution to the understanding of this theme ethics and morals in the right. In his work "what is justice", the German scholar so is expressed:

While recognizing the right as the social order specific coercive technique, we can compare it with other social orders which, in part, they pursue the same objectives that the law, but by different means. The law is specific social medium, not an end. The law, morality and religion - all three prohibit murder. But the law does so providing that: If a man commits murder, another man, designated by law, applies against the killer, some degree of coercion prescribed by the legal order. Morality simply require: thou shalt not kill.

It is noteworthy that although morale has not the power and strength to establish a sanction for their disobedience, as does the right, still it cannot be neglected by scholars of law, since even before the right positivado with their moral standards and concepts already was used by primitive societies as a means to guide and lead the relationships in the social conviviality.

Therefore, the distinction between the moral and legal principle is a fine line and they often go together and next and which are separated only by its effects. Let us take as an example a son that when passing by his father and receives a compliment does not reciprocate the same courtesy, or even distracts, such behavior is a moral offense for which there is a legal pain. However, if this same son, to be greeted by his father causes a personal injury, in this case commits crime provided for in planning and must be punished.

For this reason, Chaïm Perelman (1996:289), the great philosopher of Brussels and one of the greatest philosophers of the 20th century. XX, to address this theme and moral law, left the following registered:

Traditionally, studies devoted to the relations between law and morality insist, in a Kantian spirit, in what the distinguished: the right governs the behavior; the moral emphasizes the intention, the law establishes a correlation between the rights and 
obligations, the moral duties prescribed that do not give rise to subjective rights, the law establishes obligations sanctioned by power; the moral sanctions organised escapes. Lawyers, dissatisfied with a positivist conception, statistics and formalist, insist on the importance of the moral element in the operation of the law, in the role that they play the good faith, bad faith, malicious intent, morality, and so many other notions whose ethical aspect cannot be scorned.

By the words of the philosopher, scholar of Brussels can already get an idea of the extent that morality and ethics play in the application of law to the present day. We live in a society where the ethical and moral values to be confused with the personal and private interests, which is why these values are increasingly relegated to the background, hallmarks of a consumer society, where what matters is achieving the purposes, regardless of the means used to do so, making the old principle prevails that the ends justify the means.

Because it is exactly in that fine line between the moral and ethical values and morality that the right must walk his path, once the company comes losing these values to every generation. At the time of our fathers the simple word sealed a legal and business was carried on until circumstances.

Currently, even when surrounded by all the guarantees, securities and everything, yet you've got the real assurance that the legal business will come to term in a way are, without the intervention of the State exercising its role to coator require the rules initially compactuadas.

On this social requirement that is imposed at present, right, the way materializes in the process, through the judge's decision, brings up the entire collection of human culture in the interests of the litigants in the face of the State Court, which increasingly takes its role by delegate coator society.

What is certain is that in comparing the practice of procedure are brought into confrontation not only legal rules but also all ethical principles that the law of the process demands of litigants and even the judge himself. Flanked of freedom there is 
a whole structure of loyalty and sincerity that is required by law in the cares and judicial ties. What you should get is not just the positivada standard and formal, but also ethical and moral values as essential elements of the claim sought judicial review.

The way society is organized today, with all the instruments of social control and the increase of information through technology and economic growth on account of globalization, no longer lends itself to a mere bystander of Justice. On the contrary, lack the legal framework has shown, what is observed today, more than ever, is a society trying to take the law into their own hands, trying to fill the vacuum left by the judiciary on judicial accountability, but unfortunately operating the wrong way, making, often under the cloak of Justice, injustice still more. All this for this legal formalism, which searches only in technique and improvement of laws the answers to social problems, which makes it clear that this model is no longer supported by modern society.

As it is valid to note here the words of the Italian jurist Francesco Carnelutti (2004:60) that has: "If the law is an instrument of Justice, not the technique or the science enough to handle it." Is evidenced by the words of the Italian jurist ínclito the practical application of law, which you do by Justice carried out in legal conflicts, requires more than Legal techniques and management standards for justice. The big question you can't hide is whether the direct application as it is made these days, positivado, ready and formal, visa really justice. One can see that the application of the practical problems brought to the judiciary are not reply before the pre-established legal concepts and strictly formal.

It was not without reason that Jhering (2012:322) said that the practical problems do not adapt well to the paradise of the concepts in that many lawyers prefer to live. According to João Maurício Adeodato (2012:317), proposed a less dogmatic interpretation of Jhering, author which is internationally considered one of the most important for the Dogmatics of private law. 
Given that one realizes that the law must walk in search of a balance between the positivist vision normativista of Hans Kelsen, where the judge's decision must be shaped by the posta (hence positive law), and the more extreme position

proposed by the topical Viehweg, for which the decision should not keep relationship with the regulatory texts. In this respect, João Maurício Adeodato (2012:313) writes with a lot of property on the topic:

The topical Viehweg seems to lead to an "open" excessive in relation to the regulatory text, which is considered only an expression tops among others. In refusing the postulate necessary connection with dogmatic text, topical makes the "orientation by means of" a method too free and is nearing the decision-making powers.

What if attempts to rescue is this dogmatism of positive law that searches only and so only the standard set by the state their support base, to the detriment of the moral and ethical arguments in the search for justice. What is of greater importance is the current legal system, estatalmente positivado and governed by their own extremely formal rules.

As a corollary of this formal and rigid scenery, which no longer meets the wishes of modern man is that the alternative means of dispute resolution, such as mediation, arbitration, conciliation, who portray themselves as adjuncts to the judiciary in trying to do it. Such institutes bring in your midst not just an alternative to the traditional way of resolving conflicts, but a search and rescue by the moral and ethical values that manifest themselves in the action of arbitrators and mediators.

Within the scenario of these new institutes that arise in our society is that must shine as a professional lawyer's conduct, testing his ethics and moral stance in the face of shocks that appear increasingly contentious argument. On the other hand has the right of the client who sponsors; on the other hand, as an adversary, the response of the other party, which also has its patron lawyer.

It is in this context that the lawyer should exercise their arduous task in your client's defense intellectual, however, remained standing and in line with its belief in the right 
to defend and justice seeking, without forget the ethical and moral values that led his formation to the present moment, i.e. all your ethical and moral heritage that was being formed in the course of his earthly career.

\section{ETHICS AND MORALS IN THE REALIZATION OF JUSTICE}

Once analyzed the relationship between ethics and morals, law is valid address the other side of the coin, which is the ethics and morals in the execution of Justice. If the positivado law, as is put today, search only the standard State-controlled and rigidly formal, without taking into account the ethical and moral values and the morals established by society, it's worth making a serious reflection on the contribution of ethics and morals in the realization of Justice.

It is known that the object's moral ethics. The word morality derives from the Latin, meaning "customs", which, in turn, is the part of science that takes care of well, morality essential to man's social life. Is the set of rules for human conduct as virtue. So, the moral is indispensable to the content of the right, especially when it comes to implementation of the jurisdictional provision, which takes place by means of Justice.

The science of duties is known as ethics and the axiológicos principles that regulate them, cannot do without ethics. According to the distinguished jurist Miguel Reale: "ethics is the science of normative standards." Only the human being holds this legacy, which differs from other living creatures, as already mentioned at the beginning of this text.

Is valid here the words of José Renato Nalini (1997:30), which is known as one of the most important theorists of the study of ethics in Brazil, which expressed:

Ethics is the science of the moral behavior of men in society. It is a science because it has object itself, its own laws and proprietary method. The object of moral ethics. The moral is one of the aspects of human behavior. The expression derives from the Roman Word mores with a sense of manners, set of standards acquired by habit reiterated of his practice. 
Therefore, one can assume that ethics is the science that studies the acts of human conduct in social context based on loyalty and decency, in smoothness of acts and in dignity of the posture, so that the search for truth is the larger target to be achieved, above personal and vested interests of the passions. Unfortunately, what is observed is that the personal interests have overcome the moral and ethical values and the real desire of Justice, and it is this situation that can no longer be sustained in this globalized and information society.

What cannot be forgotten is that ethics becomes, in this current context, a prerequisite in order to live a righteous life in this globalized society. Without ethics is unbearable the life in society, and loyalty, which is its main virtue, should not only guide the relationship, but to become the core of its very essence.

It is not without reason that the study of ethics comes over millennia and the ages and it was cause for concern for the ancient Greece and classical erudition, whose contributions should be considered until today when it comes to ethics and moral theme.

You can, just by way of example, name Aristóteles9, who admitted at a young age as a disciple of Plato (who at 41 years was appointed by Philip of Macedon to tutor of Alexander the great) and inexhaustible source of human wisdom, dedicated to his son Nicomachus, born of his second marriage of Herpile of Stageira, one of his works on ethics that still today is published in every part of the world.

According to Robison Barone (2012:23), in his lawyer's professional ethics primer, cites the estagirista as follows: ". .. This is not theoretical study as others, because we studied not to know what is the virtue, but to be good, that otherwise would not do you any good" (book II of the Nicomachean Ethics).

Still, Miguel Reale (1994:24), another important jurist of the national scene, teaches that Aristotle, in the eighth book of the Nicomachean Ethics, develops his theory of Justice and he says: 
... the adjective of unfair applies to two kinds of individuals: 1) for those who disobey the law; 2) to those who want to receive more than their share, i.e. the part that by law they should be granted. In contrast, the fair is what obeys the law and what is content with his part.

Could not help but remember the illustrious Baruch Spinoza (2010), or Bendictus Spinoza, as he himself used to sign in his writings, which also bothered with this theme of ethics, developing a hermetic style, since the definition of God, through the paths in search of the freedom of the soul to the power of reason.

There is, therefore, by the words of these noble thinkers, that ethics has its predominant role in the implementation of the law and in the quest for justice. In theory too, disassociated from practice has hampered and hit the course of the judiciary over the years. It is worth reiterating what has been spoken about the complexity of the issues that are emerging in this globalized society.

What is certain is that world history is being written in a dizzying speed and accelerated, unlike past generations, where the advances were given the slow steps, and had the right conditions to a certain extent, to sustain itself and respond adequately to the concerns of citizens.

Today, with the advancement of science, the new discoveries in the genetic field, miracles and scary internet growth, life generated in laboratories, the cloning of human beings, the longevity of life, the flow of news, the fascination with the computer and the epidemic of cellphones, modern man no longer has the same certainty that their ancestors. Now everything is relative: the transmuda today on yesterday in the speed of an atom.

Within that all development and cutting-edge technology, the only thing the man failed, until now, was the magic formula of solidarity, respect for the other man, not the worst and most cruel nature predator. Unfortunately, for disenchantment this humanity, which enchants with cutting-edge technology, and the great discoveries and advancement of science, the terror became the ethical stance of the other, which acts 
fiercely as a mindless animal, not just foreign, but also law usurping if raging against any who want to protect such interests.

Within this context, it is understood that morality and ethics are key actors for the rescue of that society corrupted and eager for law and justice. Today, more than ever, there is an urgent need to rehabilitate the ethics in our society in order to bring the man back to his dignity. The ways of violence, selfishness, pride, and indifference for his similar, are the foundations of the loss of morality and ethics. It is not enough to recognize the dignity of the human person in the normative act if the personal conduct experienced in society has been guided by her.

What is certain is that ethics and morals, once redeemed, will be thrusters and drivers to a future of hope and promise for mankind, that although faced with so much technology and development, has turned the petty practices and primary, that more away men of social conviviality that integrate. This is the great challenge to modern societies, this is the role of ethics in this threshold of the third millennium.

\section{THE RELEVANCE OF THE RIGHT FOR THE MODERN MAN}

The relevance that the right plays in modern society's structural crisis dealt fulcralmente, disseminated and expresses that descortinamos in our country which ends up generating a string of the most adverse reactions are rampant. The lack of moral and ethical values there begin by rulers who, instead of giving example of smoothness and probity, prefer to go the opposite path, anchored under the cloak of impunity, that revolt the citizen who pays their taxes and struggle to maintain a decent life and correct. For another shift, some citizens appalled by this situation resolve to act the same way, under the rationale that if the error comes from up there's no reason not to act the same way.

This anarchic panorama and chaos is that citizens face in their day to day and not get tired to ask until when will continue watching all this powerless, without prospects for changes, involved in a legal system that, with its complex set of sterile, laws cannot create such citizen defense mechanisms that maintains the State structure with its 
heavy taxes no concrete return. What is certain is that the possibility or prospect of any change in this state of things should go through serious and urgent consideration of the legal institutes and their application in society, which has left something to be desired in the jurisdictional provision.

There's a lot of material written on this topic, and the trend over time is that more jurists and scholars of the right back, your eyes to this problem, in the sense of a change of direction of the directions that the right has taken, not only in our society but, why not say, in the world as a whole, namely, the failure to respect the interests of the citizen that seeks justice, to the detriment of this rampant corruption that rages and disgrace the judiciary, exactly on account of mere personal interests.

For Lênio jurist Streck (2009) the right can't fill that gap in our legal system, which perpetuates the politics of impunity and the unpreparedness of the judiciary not to meet the aspirations of the citizen, not for lack of foresight in the legal system, if not because of what he calls a "crisis". What the jurist Gaucho proposes is a paradigm shift from the current legal model deploying in our society, which is very far from the current reality in our country.

It is exactly this "crisis" detected by the Rio Grande water divider jurist who will conduct the conduct of counsel in this complex and globalized society. The old crimes so disgusted by the morals of the primitive Caveman go back now to be committed with an even greater cruelty. Add to that other crimes of our generation, as the electronic crimes such as the cloning of credit cards, bank balances criminal movement through electronic balances, sending mendaz emails with links that seek to capture passwords for criminal purposes, among others that only the human mind is able to weave and run.

Well, it's within that context chaotic and cluttered that we found the relevance of law for modern man, because the right, in their quest for Justice, is the center of consideration of all these troubles that are the modern man. Since the personal dramas of family law with his cold health, until the absolute immobility of anything we can do in the face of the slaughter of innocent lives at the hands of a downed "Punisher" insane 
and thirsty for revenge, the right should be reconsidered seriously to contemplate the social ills that emerge the modern man in complete bewilderment and helplessness in the face of facts that presence every day in society.

The relevance of the right if you do view on the moral society involution with the conduct of public managers, who Excel in making the law an instrument of his will, against the interests of the governed awkward and inept in dealing with this problem. The right must resound the personal and ideological interests and if you throw in the search for this scenario changes that now presents itself.

The Empire of brute force has been what has prevailed in our society. In dealing with infringing rights the dishes of the scales of Justice never oscillate for the citizen before the State, much less in favour of the poor facing the more rich, or even before the privileged against an anonymous.

Just to be a pale notion of what is spoken, the rules of civil procedure establish privileges in favour of the public entity, with quad to defend himself and to double, and did we mention that the State itself-judge, in the person of judge, can appeal against his own decision every time she is issued against the State.

And to make matters worse, the proposed judicial reforms in our society are never in favor of the citizen litigator; on the contrary, all the reforms in Brazil has turned against the litigant, in a vain attempt to try to convince society that justice is slow and that the delay in providing judicial review not only of the judiciary itself.

This dates back to the current moment we're living in, which is a insatiable quest for rehabilitation of ethics and morals in the world, in such a way that a minimum standard of conduct in acts of life in society and, in the case of Justice, in all that concerns the rights of the citizen. Lawyers, judges, prosecutors, all together should be builders of a new legal reality, in the constant search for ethical and moral values in pursuit of Justice.

Alternative conflict solution institutes like the already mentioned, mediation, conciliation and arbitration, are welcome in this rebuilding process and the search for Justice, since 
it doesn't claim to substitution of the judiciary, but comes as supporting cast of this search for something new and that, in fact, fill in the ideals of Justice forgotten and left aside throughout history.

\section{CONCLUSION}

Before all that was spoken, the right needs to abandon this dogmatic and closed assuming at the moment and must walk towards a more plural. In this globalized world, with all the strands have pointed out, there is no more room for a rigid, univocal vision and extremely formal, on the contrary, one can speak now in multiplicity of social actors (lawyers, judges, psychologists, technicians) and pluralism of legal institutes which best meets the concerns that modern society, including arbitration, mediation and conciliation.

The current moment leads to replacement of the individualization of the role of the judge in a process of shared responsibility of other actors involved in the collective process of social changes (the actors outside the judiciary, like the pros retromencionados), all United in search of a solid, palpable and concrete solution to meeting the needs of current man. The judiciary must promote and facilitate the production of experiences that promote the connection between himself and society instead of disjunction, of fragmentation and remoteness of the citizen of your longing for justice.

In this note, the judiciary itself should encourage partnerships and harmonization of legal practices with the institutes already mentioned that if you know by experience, has been able to give a more adequate and satisfactory return to the citizen. Should not exist here afraid of competition, much less the fear of seeming contradictions that may come to emerge in the midst of this process of change. The contradictions must be worked and not deleted, since even though some of them may seem a priori, insurmountable, yet they must not remain paralysed or leakage, and the history of science is made of construction and deconstruction of paradigms and overcoming of paradoxes. 
Therefore, for any change there is need for the judiciary to open up the production of experiences that encourage the multiplicity of knowledge and legal practices, encouraging the partnership, even between differing perspectives and theories of the current "status quo". There must be the search for dialogue with the ' social movements ' and other actors that deconstruct the traditional forms and burocratizadas of citizen participation in their own history.

Today, more than ever, there is an urgent need to understand that legal-political role is playing the challenges that present themselves today to the modern man (or postmodern) and realise that all production of work aimed at structural change has social implications, or better saying, that all production comes from certain changes and multiple power relations and force fields.

The walk to the change process, open to the critical sense and transformative potential, depends on the work of critical self-assessment judiciary about the meaning and the consequences of their way of acting. There is need for legal practices are based on the interaction with social needs, with the challenges of globalisation, always making a counterpoint with the current situation of the judiciary, which is scrapped and no minimum conditions to meet the aspirations of the citizens, face excessive demands in place there.

For this reason, the judiciary has to recognize and legitimize other actors who are willing to contribute to the solution of disputes and citizen satisfaction. Instead of the issue of conflict of jurisdiction the judiciary should act to sit at the table with the other professionals in tune with the vital needs of man, beyond the problems singled out and the differences noted. That would be a giant step towards a change of ethics-politics, inductor and driver of the reflection aimed at not just a self-criticism, but also a real change that seeks to put the right on your true path, which is the pursuit of Justice in a globalized world, without forgetting the ethics and morals, and pilasters of a genuine guiding democratic society based on the rule of law. 


\section{BIBLIOGRAPHICAL REFERENCES}

ADEODATUS, João Maurício. Ethics \& Rhetoric. 5th Edition. São Paulo: Saraiva, 2012

João Maurício. Legitimation by legally organized procedure: notes on the theory of Niklas Luhmann. In: Ethics and rhetoric: towards a theory of Legal Dogmatics. p. 53-80, São Paulo: Saraiva, 2002.

BARONI, Robison. Primer and Professional Ethics Lawyer. 3rd ed. LTR Editora Ltda:

BOBBIO, Norberto. Legal positivism: lessons of jurisprudence. Translated by Márcio Pugliesi, Edson Bini, Carlos e. Rodrigues, São Paulo: icon, 1995.

. General theory of politics. Daniela translation Beccaccia Versiani, Rio de Janeiro: Campus, 3. Reprint, 2000.

. Theory of the legal system. 10. Ed. Translation of Maria Celeste Lamb Milk dos Santos, Brasília: Ed. University of Brasília, 1997.

Francesco CARNELUTTI. What gave birth to the right. Ricardo Rodrigues translation Range. 1st Ed. Campinas: Editora Russel, 2004.

DWORKIN, Ronald. The Empire of the right. Martins Fontes: São Paulo, 2007. P. 4

Faria, José Eduardo, law and economic globalization - implications and perspectives, São Paulo: Malheiros, 2010, 1st Edition, 3rd draw.

FERNANDEZ Jr., introduction to the study of law: technique, decision, domination. 3. Ed. São Paulo: Atlas, 2001.

SON, Willis Santiago War. Theory of Legal Science. 2nd ed. Sami: São Paulo, 2009.

HABERMAS, Jürgen. Law and democracy: between facticity and validity. 4. Ed. vol. 1. Translation of Flavius Beno Sienbeneichler, Rio de Janeiro: Brazilian Time, 1997. 3 v. 
Rudolf Von JHERING. The fight for the right. Martin Claret: São Paulo, 2003.

KELSEN, Hans. The problem of Justice. 2. Ed. Translation of João Baptista Machado, São Paulo: Martins Fontes, 1996.

. What is Justice-Justice, the law and politics in the mirror of science. 3rd ed. São Paulo: Martins Fontes, 2001.

. General theory of law and State. 3. Ed. Translation by Luís Carlos Borges, Sao Paulo: Martins Fontes, 1998.

. PURE THEORY OF LAW. Translate João Baptista Machado. 6 ed. São Paulo: Martins Fontes, 1999, page 1.

NALINI, José Renato. General and professional ethics. Rvista of courts: São Paulo, 1997.

Nunes, Pedro. Dictionary of Legal Technology. 13th ed. Renew: Rio de Janeiro, 1998.

Chaïm Perelman. Ethics and law. Martins Fontes: São Paulo, 1996.

REALE, Miguel. A new ethic for the Judge. Coord. José Renato Nalini. Magazine of the courts: São Paulo, 1994.

SPINOZA, Baruch. The Ethics. Trad. Lívio Xavier. Ed. Tecnoprint S.a.-Ediouro: São Paulo.

VALLE, Gabriel. Étiva and law. 1st ed. Synthesis Publisher: São Paulo, 1999.

SETHI, Vincent Paul. Standards of professional ethics. Legal Publisher Ltda: fortress, 1989.

, Eugenio Raul ZAFFARONI-STYLE LEAPS. Judiciary, crisis, successes and misunderstandings. Trad. From Juarez Tavares. Ed. Magazine of the courts: São Paulo, 1995. 